\begin{tabular}{c} 
International Journal of Scientific World, $4(1)(2016) 23-26$ \\
International Journal of Scientific World \\
SPC \\
Website: $\begin{array}{c}\text { www. sciencepubco.com/index.php/IJSW } \\
\text { doi: } 10.14419 / \text { ijsw.v4il.6066 } \\
\text { Research paper }\end{array}$ \\
\hline
\end{tabular}

\title{
Phytochemical screening, mineral composition and in vitro antioxidant activities of Pterocarpus mildbraedii leaves
}

\author{
Usunobun Usunomena*, Igwe V. Chinwe \\ Department of Basic sciences (Biochemistry unit), Faculty of Basic and Applied sciences, Benson Idahosa University, \\ P.M.B 1100, Benin City, Edo State, Nigeria, +2348034174871 \\ *Corresponding author E-mail: uusunobun@biu.edu.ng, usunsquare@yahoo.com
}

\begin{abstract}
Background: Pterocarpus mildbraedii is used in some Nigerian tribes in the treatment of headaches, pains, fever, convulsions, and respiratory disorders. This study was carried out to ascertain the phytochemicals, minerals and in vitro antioxidant activities of Pterocarpus mildbraedii leaves.

Methods: Qualitative phytochemical screening was carried out using standard procedures while Mineral analysis was carried out using Atomic Absorption Spectrophotometer (AAS). Also, antioxidant activities of Pterocarpus mildbraedii leaves were evaluated using reducing power ability and 2,2-Diphenyl-1-picrylhydrazyl (DPPH) radical scavenging assays.

Results: Result on phytochemicals reveals the presence of flavonoids, saponins, alkaloids, tannins. Mineral analysis showed calcium $(1283 \mathrm{mg} / \mathrm{kg})$ to be higher in concentration and manganese $(4 \mathrm{mg} / \mathrm{kg})$ least in concentration $(4 \mathrm{mg} / \mathrm{kg})$. Other analysed minerals include sodium $(603 \mathrm{mg} / \mathrm{kg})$, potassium $(1048 \mathrm{mg} / \mathrm{kg})$, magnesium $(778 \mathrm{mg} / \mathrm{kg})$, zinc $(25 \mathrm{mg} / \mathrm{kg})$, iron $(146 \mathrm{mg} / \mathrm{kg}), \mathrm{phosphates}(1002 \mathrm{mg} / \mathrm{kg})$, etc. In vitro antioxidant activity results show that Pterocarpus mildbraedii possess potent but dose-dependent reducing power ability and free radical scavenging activity against 2,2-diphenyl-1-picrylhydrazyl (DPPH) radicals.

Conclusion: The presence of phytochemicals such as flavonoids, saponins, alkaloids and tannins in Pterocarpus mildbraedii provides some biochemical basis for the ethno pharmacological uses of the plant. Also the information provided in this research study may help to spread the ethno botanical uses of Pterocarpus mildbraedii leaves to other parts of the World. The findings clearly demonstrate that Pterocarpus mildbraedii leaves have promising antioxidant property and needs further evaluation to exploit its therapeutic potential.
\end{abstract}

Keywords:2; 2-Diphenyl-1-Picrylhydrazyl (DPPH); Minerals; Phytochemicals; Pterocarpus mildbraedii; Reducing power.

\section{Introduction}

Pterocarpus mildbraedii leaves locally known as "Oha" in Eastern Nigeria are used as vegetables in the preparation of soup in Nigeria. Pterocarpus mildbraedii Harms is a green leafy vegetable which grows more like a big tree reaching a height of $2 \mathrm{~m}(6.6 \mathrm{ft})$ and having stem diameter of $20 \mathrm{~m}(0.79 \mathrm{inch})$. Pterocarpus mildbraedii Harms has a smooth, gray or pale brown bark, exuding red gum when cut. Two species are recognized locally Pterocarpus mildbraedii Harms (Oha) and Pterocurpus santalinoides (uturukpa) [1]. Some tribes in Eastern and Southern Nigeria use the leaf extracts from Pterocarpus mildbraedii in the treatment of headaches, pains, fever, convulsions, and respiratory disorders and as antimicrobial agents [2]. Apart from the leaves being consumed by humans as vegetables, livestock also browse on them. Other uses include timber, gum or resin and dyes production [3] as well as analgesia from the bark [4]. The objective of this study is to screen for phytochemicals, minerals as well as in vitro antioxidant activities of Pterocarpus mildbraedii leaves.

\section{Materials and methods}

\subsection{Collection, identification and preparation of plant} materials
The fresh leaves of Pterocarpus mildbraedii were collected from a local farm in the south eastern part of Nigeria. Identification and authentication were carried out after which the leaves were washed and air dried at room temperature for sixteen (16) days. They were grounded into fine powder using an electric blender and stored in a cool dry container until use for analysis.

\subsection{Phytochemical analysis}

Qualitative phytochemical screening to determine the presence of alkaloids, tannins, saponins, anthraquinones, flavonoid and glycosides using standard methods as described by [5-9] were carried out.

\subsection{Mineral analysis}

Mineral analysis was carried out using Atomic Absorption Spectrophotometer (AAS) as previously determined by Usunobun and Okolie, [10-11].

\subsection{Determination of reducing power ability}

The reducing power activity of Pterocarpus mildbraedii leaves was carried out using the reducing power method. A mixture containing $2.5 \mathrm{ml}$ of $0.2 \mathrm{M}$ phosphate buffer ( $\mathrm{pH} 6.6$ ) and $2.5 \mathrm{ml}$ of $\mathrm{K}_{3} \mathrm{Fe}(\mathrm{CN})_{6}(1 \% \mathrm{w} / \mathrm{v})$ was added to $1.0 \mathrm{ml}$ of stock Pterocarpus 
mildbraedii leaves filtrate $(0.2-1.0 \mathrm{mg} / \mathrm{ml})$ prepared in distilled water. The resulting mixture was incubated for $20 \mathrm{~min}$ at $50^{\circ} \mathrm{C}$, followed by the addition of $2.5 \mathrm{ml}$ of TCA $(10 \% \mathrm{w} / \mathrm{v})$, followed by centrifugation at $3000 \mathrm{rpm}$ for $10 \mathrm{~min} .2 .5 \mathrm{ml}$ of the supernatant was mixed with $2.5 \mathrm{ml}$ of distilled water and $0.5 \mathrm{ml}$ of $\mathrm{FeCl}_{3}$ $(0.1 \% \mathrm{w} / \mathrm{v})$. The absorbance was measured at $700 \mathrm{~nm}$ against reagent blank sample. Increased absorbance of the reaction mixture indicates higher reducing power of Pterocarpus mildbraedii leaves.

\subsection{2,2-diphenyl-1-picrylhydrazyl (DPPH) radical scav- enging ability}

The DPPH method was used for the determination of DPPH free radical scavenging activity of Pterocarpus mildbraedii leaves as follows: DPPH $(1 \mathrm{ml}, 0.135 \mathrm{mM})$ prepared in methanol was mixed with $1.0 \mathrm{ml}$ of stock Pterocarpus mildbraedii leaves filtrate ranging in concentration from 0.2 to $1.0 \mathrm{mg} / \mathrm{ml}$. The reaction $\mathrm{mix}$ ture was then vortexed thoroughly and left in the dark at room temperature for $30 \mathrm{~min}$. The absorbance was measured at $517 \mathrm{~nm}$. The scavenging ability was calculated using the equation: DPPH scavenging activity $\left.(\%)=\left[\left(\mathrm{Abs}_{\text {control }}-\mathrm{Abs}_{\text {sample }}\right)\right] /\left(\mathrm{Abs}_{\text {control }}\right)\right] \times$ 100 ,

Where: $\mathrm{Abs}_{\text {control }}$ is the absorbance of DPPH + methanol and Ab$\mathrm{s}_{\text {sample }}$ is the absorbance of DPPH radical + sample (sample or standard).

\subsection{Statistical analysis}

Data obtained from this study were expressed as mean value \pm standard deviation.

\section{Results}

Phytochemical screening reveals the plant to contain flavonoids, saponins, alkaloids and tannins as shown in table 1
Table 1: Phytochemical Screening of Pterocarpus mildbraedii Leaves

\begin{tabular}{ll}
\hline Phytochemicals & Pterocarpus mildbraedii \\
\hline Flavonoids & $+\mathrm{ve}$ \\
Saponins & $+\mathrm{ve}$ \\
Alkaloids & $+\mathrm{ve}$ \\
Tannins & $+\mathrm{ve}$ \\
Anthraquinones & $-\mathrm{ve}$ \\
Glycoside & $-\mathrm{ve}$ \\
\hline Where & -
\end{tabular}

Where + ve $=$ positive, - ve $=$ negative

The result of the minerals as shown in table 1 shows Pterocarpus mildbaedii to be higher in calcium $(1283 \mathrm{mg} / \mathrm{kg})$ and least in manganese $(4 \mathrm{mg} / \mathrm{kg})$. other minerals includes magnesium $(778 \mathrm{mg} / \mathrm{kg})$, potassium $(1048 \mathrm{mg} / \mathrm{kg})$, sodium $(603.20 \mathrm{mg} / \mathrm{kg})$, iron $(146.45 \mathrm{mg} / \mathrm{kg})$, zinc $(25.10 \mathrm{mg} / \mathrm{kg})$, copper $(9.55 \mathrm{mg} / \mathrm{kg})$, and chromium $(7.90 \mathrm{mg} / \mathrm{kg})$

Table 2: Mineral Composition of Pterocarpus mildbraedii Leaves (mg/kg) Minerals Pterocarpus mildbraedii $(\mathrm{mg} / \mathrm{kg})$

Calcium $\quad 1283.00 \pm 5.15$

Magnesium $\quad 778.00 \pm 2.21$

Potassium $\quad 1048.55 \pm 4.17$

Sodium $\quad 603.00 \pm 3.01$

Phosphate $\quad 1002.10 \pm 3.34$

Iron $146.45 \pm 2.22$

Zinc $\quad 25.10 \pm 1.02$

Copper $\quad 9.55 \pm 1.76$

Manganese $\quad 4.00 \pm 0.12$

Chromium $7.90 \pm 0.99$

Values are means \pm SD for 2 determinations

The results of antioxidant activity (DPPH) of Pterocarpus mildbraedii leaves is presented in figure 1. In DPPH assay, the antioxidant activity of the leaf sample percentage ranged from $60.93 \%$ to $80.99 \%$. Increase in Pterocarpus mildbraedii concentration resulted in increase in the scavenging activity.

The results of reducing power activity of Pterocarpus mildbraedii leaves shown in figure 2 showed a significant increase in the scavenging activity with increasing concentration as shown by the increase in absorbance at higher concentration of Pterocarpus mildbraedii.

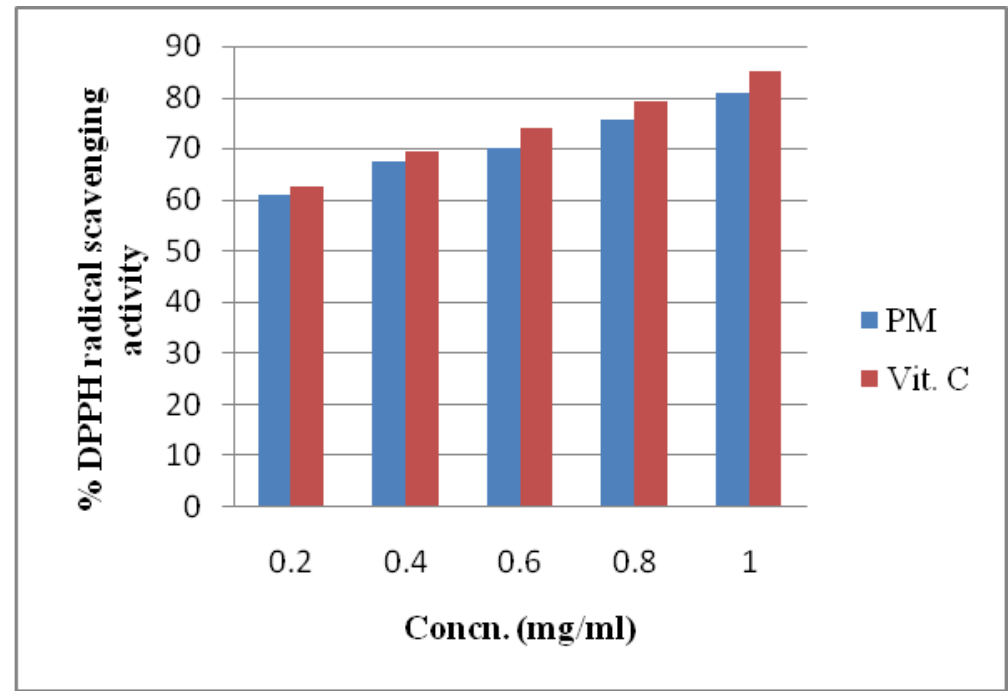

Fig. 1: DPPH Radical Scavenging activity of Pterocarpus mildbraedii (PM) Leaves. 


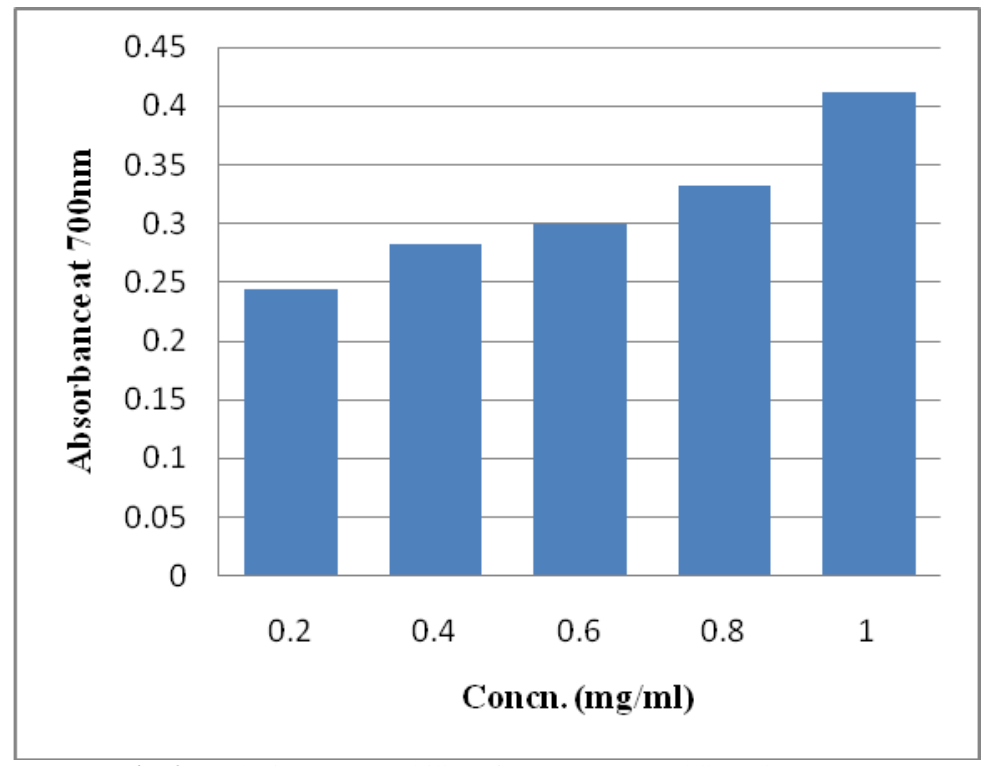

Fig. 2: Reducing Power Ability of Pterocarpus mildbraedii Leaves.

\section{Discussion}

Different authors [12-13], have noted that consumption of fruits and vegetables help to prevent diseases such as cancer, ulcers, etc; and as well remedy disease conditions such as gastrointestinal disease, malaria, hepatitis, pile, liver cirrhosis, etc [14-20]. Studies have shown that these fruits and vegetables are able to play these vital roles due to the presence of chemical constituents found in them, which are bioactive in nature [8-9, 20-22]. These bioactive compounds are termed phytochemicals.

The phytochemical screening of Pterocarpus mildbraedii leaves showed that it contained alkaloids, flavonoids, tannins, saponins. These phytochemicals exhibit a wide range of biological effect as a consequence of their antioxidant properties [20]. Apart from antioxidant functions, flavonoids also function in protection against allergies, inflammation, free radicals, platelet aggregation, microbes, ulcers, hepatoxins, virtuses and tumors. Flavonoids reduced cancer by interfering with the enzyme that produces estrogen. They reduce edema formation and prevent platelet stickiness and hence platelet aggregation, [23]. The presence of tannins in Pterocarpus mildbraedii supports its potential usage in treatment of ulcers as well as wounds cuts to accelerate healing. The presence of alkaloids in the leaves of Pterocarpus mildbraedii suggests an increase in disease resistance and stress as well as analgesic and anti-inflammatory potentials. Alkaloids are known for their bitter and sweet sensations. Their resemblance with neurotransmitters had made possible their use as powerful analgesics. They also have anti-malarial and anti-leukemic properties [24].

The leaves of Pterocarpus mildbraedii showed presence of saponins which are important dietary and nutritional reserves [25]. Saponins are glycosidic in nature [26]. They have an expectorant action useful in the management of upper respiratory tract infections. According to Cheek, [27], saponins are involved in the treatment of hypercholesterolemia. Kubmarawa et al [28] reported the importance of alkaloids, saponins and tannins in various antibiotics used in treating common pathogenic strains.

The leaves of Pterocarpus mildbraedii were also found to contain mineral elements such as calcium, potassium, magnesium, phosphorus, sodium, iron, zinc etc and these elements are very important in human and nutrition. They are required in repairing worn-out cells, strong bone and teeth, building blood cells and maintaining osmotic balance [29]. Zinc plays an important role in medicines, foods and in industries in the prevention of corrosion. Magnesium is a composition of chlorophyll and it is an important content in connection with Ischemic heart disease and calcium metabolism in bones [30]. Iron is an essential trace element for haemoglobin formation, normal functioning of central nervous system and in the oxidation of carbohydrates, protein and fats [31].

Potassium content of Pterocarpus mildbraedii $(1048.55 \mathrm{mg} / \mathrm{kg}$ ) is high when compared to $363.05 \mathrm{mg} / \mathrm{kg}$ of Annona muricata and $627.98 \mathrm{mg} / \mathrm{kg}$ of Vernonia amygdalina [10-11] but low when compared to $128.33 \mathrm{mg} / 100 \mathrm{~g}$ of Celosia argentea [32]. Iron content of Pterocarpus mildbraedii $(146.45 \mathrm{mg} / \mathrm{kg}$ ) compared favorably with $139.5 \mathrm{mg} / \mathrm{kg}$ of Annona muricata but is low compared with $322 \mathrm{mg} / \mathrm{kg}$ of Vernonia amygdalina as reported by Usunobun and Okolie [10-11] and 35.16mg/100g of Celosia argentea [32]. Magnesium content of Pterocarpus mildbraedii $(778 \mathrm{mg} / \mathrm{kg})$ is low when compared to $122.50 \mathrm{mg} / 100 \mathrm{~g}$ of Celosia argentea [32], $9619 \mathrm{mg} / \mathrm{kg}$ of Annona muricata and $6813.60 \mathrm{mg} / \mathrm{kg}$ of Vernonia amygdalina [10-11]. Calcium content of Pterocarpus mildbraedii $(1283 \mathrm{mg} / \mathrm{kg})$ is low when compared to $295 \mathrm{mg} / 100 \mathrm{~g}$ of Celosia argentea [32], $11,183 \mathrm{mg} / \mathrm{kg}$ of Annona muricata and $12641.76 \mathrm{mg} / \mathrm{kg}$ of Vernonia amygdalina [10-11]. Zinc content of Pterocarpus mildbraedii $(25.10 \mathrm{mg} / \mathrm{kg})$ is high when compared to $8.34 \mathrm{mg} / \mathrm{kg}$ of Annona muricata and $14.23 \mathrm{mg} / \mathrm{kg}$ of Vernonia amygdalina [10-11] but low when compared to $5.42 \mathrm{mg} / 100 \mathrm{~g}$ of Celosia argentea [32]. Sodium content of Pterocarpus mildbraedii $(603.20 \mathrm{mg} / \mathrm{kg})$ compared favorably with $694.86 \mathrm{mg} / \mathrm{kg}$ of $A n-$ nona muricata but high when compared to $483.0 .6 \mathrm{mg} / \mathrm{kg}$ of Vernonia amygdalina as reported by Usunobun and Okolie [10$11]$.

DPPH is a stable free radical generally used to determine the ability of compounds to scavenge free radicals. Free radicals are involved in many disorders like cancer and liver disease. The most appropriate and fastest way of evaluating the antioxidant and free radical scavenging activity of plants is DPPH stable free radical method. The free radical scavenging activity was measured as decolorizing activity following the trapping of the unpaired electron of DPPH as shown in Figure 1. The free radical scavenging activity of Pterocarpus mildbraedii leaves by DPPH method exhibited a concentration-dependent response (Figure 1) with the highest concentration $(1 \mathrm{mg} / \mathrm{ml})$ found to be the most active free radical scavenger exhibited $(88.3 \%$ inhibition at a concentration of $1 \mathrm{mg} / \mathrm{ml})$ and the lowest concentration $(0.2 \mathrm{mg} / \mathrm{ml})$ being the least active free radical scavenger.

In reducing power activities, the antioxidant ability of Pterocarpus mildbraedii leaves to reduce iron (III) to iron (II) was examined and it showed that the higher the concentration, the higher the absorbance and increased absorbance of the reaction mixture indicates higher reducing power of Pterocarpus mildbraedii leaves. The reducing power ability of a compound generally depends on the presence of reductones (antioxidants), which exert antioxidant activity by breaking the free radical chain by donating a hydrogen 
atom. Pterocarpus mildbraedii leaf might, therefore, contain high amount of reductones.

In conclusion, Pterocarpus mildbraedii leaves should continue to be used as food since it contains valuable phytochemicals and minerals. The traditional medicinal use of the leaves of should also continue since it contains valuable phytochemicals which are the basis for plant medicinal starting materials, in the synthesis of new drugs.

\section{References}

[1] Uchegbu RI., Gabriel UI, Uche EE, Chioma OI \& Kenneth OA (2015). Identification of Phytochemicals Present in the Leaves of Pterocarpus mildbraedii Harms by GC/MS Analysis. IOSR Journal of Applied Chemistry 8(7), 6-10.

[2] Ogukwe CE, Oguzie EE, Unaegbu C \& Okolue BN (2004) Phytochemical Screening on the leaves of Sansevieriatri fasciata. Journal of Chemistry Society of Nigeria. 29, 8-9.

[3] Keay RW. (1989). Trees of Nigeria. Claredon Press, Oxford.

[4] Akinyeye RO, Oluwadunsi A. \& Omoyeni, a (2010). Proximate, mineral, anti-nutrients, phyto-chemical screening and amino acid compositions of the leaves of Pterocarpus mildbraedi harms. Electron. Journal of Environment,Agriculture \& Food Chemistry (94) 1322- 1333

[5] Sofowora LA. (1993). Medicinal plants and Traditional Medicine in Africa. Spectrum Books Ltd, Ibadan, pp55-71.

[6] Trease GE \& Evans WC. (1985). Pharmacognosy 11th Ed., Tindall Ltd, London, pp60-75.

[7] Harbone JB. (1998). Methods of extraction and isolation. In: Phytochemical Methods. Chapman and Hall, London; Pp60-66.

[8] Usunobun U, Okolie NP, Anyanwu OG. Adegbegi AJ. \& Egharevba ME. (2015).Phytochemical screening and proximate composition of Annona muricata leaves. European Journal ofBotany, Plant science and Phytology 2(1), 18-28.

[9] Usunobun U \& Okolie PN(2016). Phytochemical analysis and proximate composition of Vernonia amygdalina. International

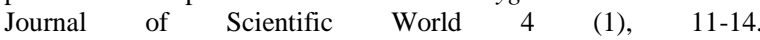
http://dx.doi.org/10.14419/ijsw.v4i1.5845.

[10] Usunobun U \& Okolie NP (2015). Phytochemical analysis and mineral composition of Annona muricata leaves. International Journal of Research and Current Development 1(1), 38-42.

[11] Usunobun U \& Okolie NP. (2015). Phytochemical, trace and mineral composition of Vernonia amygdalina leaves. International Journal of Biological and Pharmaceutical Research. 6(5), 393-399.

[12] Stray F, (1998). The national guide to medicinal herbs and plants. Tiger Books International, London. Pp.12-16.

[13] Biswas TK, \& Mukherjee B, (2003). Plant medicines of Indian origin for wound healing Activity. A Review. The International Journal of Lower Extermity Wounds 2(1), 25-39.

[14] Usunobun U, Okolie NP, \&Eze IG. (2015). Attenuation of N, NDimethylnitrosamine-induced liver Fibrosis in rats by ethanolic leaf extract of Annona muricata. Saudi Journal of Medical and Pharmaceutical Sciences1(2), 62-69.

[15] Usunobun U, Okolie NP \& Eze IG (2015). Inhibitory Effect of Vernonia amygdalina on Dimethylnitrosamine(DMN)-induced Liver Fibrosis in Rats. International Journal of Clinical Pharmacology and Toxicology4(4), 179-184.

[16] Dalziel JM. (1937). the useful plants of West Tropical Africa (New York: Longman) 1st edn, pp. 433-435.

[17] Walker ARP. (1978): The relationship between bowel cancer and fibre content in the diet. American Journal of clinician \& Nutrition $31, \mathrm{~S} 245-\mathrm{S} 251$.

[18] World Health Organization, WHO (1976). African Traditional Medicine. WHO: Afro-Tech. Rep.

[19] Bagchi M, Milnes M, Williams C, Balmoori J, Ye X, Stohs S, \& Bagchi D. (1999). Acute and chronic stress-induced oxidative gastrointestinal injury in rats and the protective ability of a novel grape seed proanthocyanidin extract, Nutrition Research 19, 11891199.http://dx.doi.org/10.1016/S0271-5317(99)00080-9.

[20] Okwu, DE., (2005). Phytochemical, vitamin and mineral contents of two Nigeria medicinal plants. International Journal of Molecular Medicine and Advance Sciences 1(4), 375-381.

[21] Duke J, (1992). Handbook of biological active phytochemicals and their activities. CRC Press, BICA Ration (FL). pp. 99-131.

[22] Akubugwo IE, Obasi NA, Chinyere GC, \& Ugbogu AE, (2008) Mineral and phytochemical contents in leaves of Amaranthus hy bridus $\mathrm{L}$ and Solanum nigrum L. subjected to different processing methods. African Journal of Biochemistry Research 2 (2), 040-044.
[23] Okwu DE \& Ndu CV (2006). Evaluation of the phytonutrients, minerals and vitamin contents of some varieties of yam (Dioscorea $S p$.)International Journal of Molecular Medicine andAdvanced Science 292, 199-2003.

[24] Angela S \& Graham W (1991). Plant Cell and Tissue Culture 91, pp.124-131.

[25] Chinedu SN, Olasumbo AC, Eboji OK, Emiloju OC, Arinola OK \& Dania DI, (2011). "Proximate and Phytochemical Analyses of Solanum aethiopicumL. and Solanum macrocarponL. Fruits," Research Journal of Chemical Sciences 1(3), 63-71.

[26] Sodipo OA,Abdulrahman FI, Akan JC \& Akinniyi JA, (2008). "Phytochemical Screening and Elemental Constituents of the Fruit of Solanum macrocarpum Linn," Continental Journal of Applied Sciences 3, 85-94.

[27] Cheek PR (1971). "Nutritional and Physiological Implications of Saponins: A Review," Canadian Journal of Animal Science 51(3), 621-632. http://dx.doi.org/10.4141/cjas71-082.

[28] Kubmarawa D, Ajoku GA, Enworem NM, \& Okorie DA. (2007). African Journal of Biotechnology6, 1690-1696.

[29] World Health Organization, WHO. (1996). World Health Organization technical series. Trace elements in human nutrition and health World Health Organization, Geneva, pp' 199-205.

[30] Ishida H, Suzuno H, Sugiyama N, Innami S \& Todokoro, T. (2000). National evaluation of chemical component of leaves stalks and stem of sweet potatoes (Ipomea batata) poir. Food Chemistry. 68, 359- 367.http://dx.doi.org/10.1016/S0308-8146(99)00206-X.

[31] Adeleye E. \& Otokiki, MKO (1999). "Proximate composition and some nutritionally valuable minerals of two varieties of Capsicum аппи," Discovery Innovations 11, 75-81.

[32] Usunobun U \& Ekpemupolo IS. (2016). Phytochemical analysis, mineral composition and in vitro antioxidant activities of Celosia argentea leaves. International Journal of Scientific World 4(1):1922. http:dx.doi.org/10.14419/ijswv4il.6064 